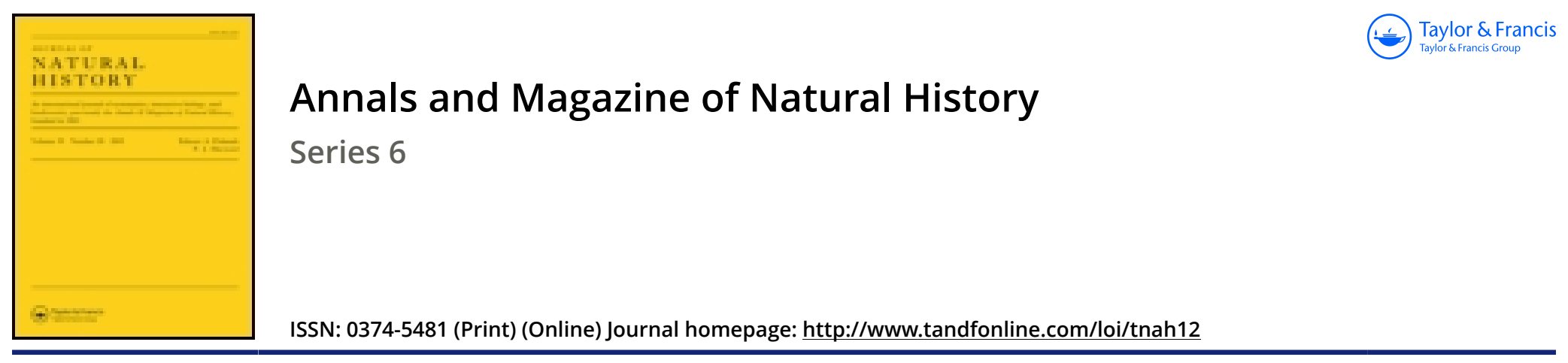

\title{
LIV.-Descriptions of new genera of Zephroniidæ, with brief preliminary diagnoses of some new species
}

\section{R.I. Pocock}

To cite this article: R.I. Pocock (1895) LIV.-Descriptions of new genera of Zephroniidæ, with brief preliminary diagnoses of some new species, Annals and Magazine of Natural History, 16:95, 409-415, DOI: 10.1080/00222939508680293

To link to this article: http://dx.doi.org/10.1080/00222939508680293

Published online: 06 Oct 2009.

Submit your article to this journal $\square$

Џll Article views: 4

Q View related articles $\square$

Citing articles: 2 View citing articles ๘ 
white, black-edged longitudinal streaks, the middle extending to the end of the snout, the outer to the eyes; tail golden; upper lip and lower parts white.

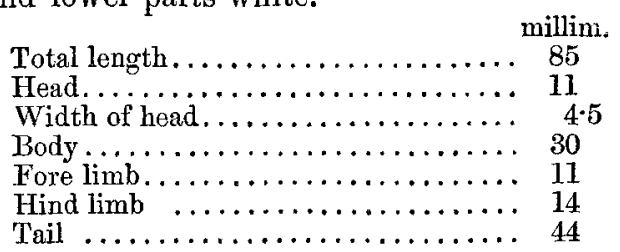

A single specimen.

Dendrelaphis papuensis.

Maxillary teeth 21 or 22. Eye as long as its distance from the nostril. Rostral broader than deep, visible from above; internasals as long as the præfrontals ; frontal once and a half to once and two thirds as long as broad, as long as its distance from the end of the snout, a little shorter than the parietals; loreal elongate; one præ- and two postoculars; temporals $2+2$; eight upper labials, fourth and fifth entering the eye ; five or six lower labials in contact with the anterior chinshields, which are shorter than the posterior. Scales in $\mathbf{1 3}$ rows. Ventrals 185-190; anal divided; subcaudals 119126. Olive-brown above, head and neck dark, blackish; a black streak on each side of the head and neck, passing through the eye; upper lip white; vertebral scales on anterior part of body lighter, edged with whitish in front; ventrals and subcaudals pale olive.

Total length 1050 millim.; tail 310.

Several specimens.

The same collection contains, among other more widely distributed reptiles, examples of Lepidodactylus pulcher, Blgr.; Lygosoma virens, Ptrs. (with 32 or 34 scales round the body); L. Mivarti, Blgr.; and Hyla infrafrenata, Gthr.

LIV.-Descriptions of new Genera of Zephroniidæ, with brief preliminary Diagnoses of some new Species. By R. I. Pocock.

Genus Spharotherium, Brandt.

Spharotherium, Brandt, Bull, Mosc. vi. p. 198, 1833 (=Oligaspis, Wood).

Resembling Zephronia in the structure of the vulva; the copulatory feet of the second pair in the male differing in being furnished with a strong stridulating-ridge. 
Tarsi as in Zephronia or approaching in structure those of Sphoropceus.

Type $S$. rotundatum, Brandt.

Distribution. S. Africa.

Sphcerotherium monticola, sp. $\mathbf{n}$.

o. Colour piceo-olivaceous.

Nuchal plate marginally punctured; the other terga coarsely but irregularly punctured.

Anal tergite punctured and hairy and marked mesially with a narrow vertical area, densely beset with piliferous punctures.

Length 17 millim.

Loc. Table Mountain (H. A. Spencer).

\section{Sphorotherium granulatum, sp. $\mathrm{n}$.}

Colour deep green, with posterior borders of tergites ferruginous.

Related apparently to $S$. rotundatum and compressum, but differing from both, as from all the other species of the genus known to me, in having the anal tergite finely and thickly granular.

Length 15 millim.

Loc. Port Elizabeth (H.A. Spencer).

\section{Genus Zoosph erium, nov.}

Closely allied to Arthrosphoera in the vulva, but having the external of the two distal laminæ of this organ deeply notched. Antenno usually long, with the apical segment cylindrical in both sexes.

Tarsi nearly intermediate in structure between those of Arthrosphcera and Zephronia.

Type $Z$. neptunus (Butler).

Distribution. Madagascar.

\section{Genus Arthrosphara, nov.}

Vulva composed of three distinct segments, one proximal and the others distal, arranged in the form of a cone.

Copulatory feet. Movable digit of anterior pair armed with lobe-like teeth and much larger than the immovable digit, with its basal portion often segmented: in the posterior pair the immovable is compressed and blade-like, with its cuttingedge finely toothed; the movable not segmented, armed posteriorly with a set of granuliform teeth and internally with two membranous processes. 
Legs truncate at the apex, the spine situated on the npper angle, some distance above the claw which is articulated to the inferior angle.

Apical segment of antennce enlarged, larger in male than in female.

'Jype $A$. heterosticta (Newport).

I)istribution. Ceylon and India.

\section{Synopsis of new Species.}

a. Margin of the second tergite not suddenly thickened on a level with the eye.

$a^{1}$. Lower edge of anal tergite distinctly grooved; colour deep green, with a

- bright yellow transverse stripe close to the hinder border of the tergite .. Wroughtoni. Kanara.

$b^{1}$. Lower edge of anal tergite not sulcate; colour greenish or yellowish, spotted with black, with a fine black stripe along the posterior border of the tergites. Thurstoni. Nilghiri Hills.

b. Margin of second tergite with a large or small but abrupt thickening on a level with the eye; lower edge of anal tergite not grooved.

$a^{2}$. The greater part of the body entirely pale yellow; the second segment mostly chestnut-brown, with a thin stripe of the same colour on the posterior border of segments 3 to $7 \ldots \ldots \ldots$ bicolor. Salem.

$b^{2}$. Colour various, mostly of a uniform dark green or brown, often mottled, but not arranged as in bicolor.

$a^{3}$. Posterior inferior angles of terga 8 to 10 thickened and out-turned; all the terga, except the extreme posterior margin, densely corrugated; irregularly mottled black and yellowish.. Hendersoni. Kodaikanal.

$b^{3}$. Posterior inferior angles of terga not thickened and out-turned, and the hinder half of the terga either finely punctured or smooth.

$a^{4}$. Colour a deep olive-yellow, spotted with black, and a large black patch on each side of the terga ...... disticta. Yercand.

$b^{4}$. Colour a deep olive-green or brown, often variegated, but not marked with a large lateral patch on the terga.

$a^{5}$. Anal tergite and posterior two thirds of the others perfectly smooth and polished; deep olive-green; mottled ........ nitida. Kodaikanal.

$b^{\tilde{5}}$. Anal tergite punctured throughout, or at least above.

$a^{6}$. Anterior half of the terga 


\section{Genus Sphreropeus, Brandt.}

Sphteropœus, Brandt, Bull. Mosc. vi. p. 200 (1833).

This genus may be recognized from Zephronia of Gray, which it resembles in the structure of its genital organs, by having the tarsi constructed as in Arthrosphcera.

Type hercules, Brandt.

The following synopsis of the species of Sphoropous is based upon those that are known to me:-

$a$. Tergites smooth, not closely punctured and not granular in front.

$a^{1}$. Laminate portion of second tergite enormously expanded ............ hercules, Br. Sumatra.

$b^{1}$. Laminate portion exceedingly small .. zonatus, $\mathrm{sp} . \mathrm{n}$. Malacca.

b. Tergites densely punctured and granular in front.

$a^{2}$. All the tergites pubescent, variegated yellow and dark green.

$a^{s}$. Antennæ and legs deep green; tergites with a distinct yellow spot on each side.$\ldots \ldots \ldots \ldots \ldots \ldots \ldots$ bimaculatus, sp.n. Singa-

$b^{3}$. Antennæ and legs (except tarsi) pale; lateral portions of tergites entirely yellow ................. variegatus, sp. n. Loc.?

$b^{2}$. Tergites not pubescent, less finely punctured and not variegated with colours.

$a^{4}$. Male with terminal fang on mandible and distal segments of first two pairs of legs enormously enlarged; anal tergite saddle-shaped and without inner crest . ............. gladiator, Poc. Sumatra.

$b^{4}$. Mandible and anterior legs normal; anal tergite evenly convex and bearing an internal crest......... Stollii, sp. n. Batavia. 


\section{Genus Zephronra, Gray.}

Zephronia, Gray, Griffith's Animal Kingdom, xiv. pl. exxxv. fig. 5; also xv. p. 796 (1832).

Vulva composed of two pieces, a proximal hairy piece bearing the aperture and a distal usually polished piece.

Copulatory feet. Movable digit of anterior pair either larger or smaller than the immovable, not strongly toothed, and with its apex often segmented off ; movable digit of posterior pair bisegmented.

Tarsi distally narrowed, claw terminal, the upper spine close to but behind the claw.

Type Z. ovalis, Gray.

Distribution. Assam, Burma, Java.

\section{Zephronia anthracina, sp. $\mathrm{n}$.}

Entirely black, shining; tergites exceedingly minutely and closely punctured, smooth in front; anal tergite with its anterior and posterior margin smooth, the rest of its surface minutely and closely punctate; lamina of second tergite very large; two spines above the claw.

Length 52 millim.

Loc. Perak (Malay Peninsula).

\section{Zephronia impunctata, sp. n.}

Allied to $Z$. anthracina and $Z$. semilovis.

Pitchy black, the posterior borders of the terga obscurely ferruginous; legs olivaceous.

Terga polished; the anal and the posterior borders of the eleventh and twelfth minutely punctulate.

Length 36 millim.

Loc. Penang (Mr. Stanley Flower, Northumberland Fusiliers).

\section{Zephronia Dollfusi, sp. n.}

Olivaceous. Tergites exceedingly finely and closely punctured throughout. Lamina of the tergite scarcely developed; anal tergite evenly convex, inner crest represented by a black tubercle. One spine above the claw.

Length 28.5 millim.

Loc. Cochin China (Adrien Dollfus).

\section{Genus Castanotherium, nov.}

Resembles Zephronia in most particulars, but differs in that 
the movable digit of the posterior pair of copulatory feet is composed of but one segment, while the immovable is widely spatulate, with a rounded apex.

Type $O$. Hosei, sp. n.

\section{Synopsis of some new Species.}

a. Tarsi armed with two spines above the claw.

$a^{1}$. Of large size (60 millim.); tergites with a wide transverse pubescent band, granular in front, punctured behind as in the rest of the species; second tergite neither grooved nor crested in front $\ldots \ldots \ldots \ldots \ldots \ldots \ldots \ldots \ldots$

$b^{1}$. Smaller (35 millim.); tergites without pubescent band, second with a crest and shallow groove in front ....... Everettii. N.W. Borneo.

b. Only one spine above the claw on the legs.

$a^{2}$. Of large size (60 millim.) ; tergites as in Hosei, but the second grooved and crested; terga yellow in front and laterally, green posteriorly ......... Whiteheadi. Kina Balu.

$b^{2}$. Of small size (about 30 millim.); tergites without transverse pubescent band, at most covered with small bristles.

$a^{3}$. Terga corroded with dense anastomosing punctures; apical antennal segment in $\&$ cylindrical and bearing only four sensory papillæ ....... porosum. Philippine Isl.

$b^{3}$. Terga less deeply punctured.

$a^{4}$. Antennæ yellow; inner crest on anal tergite long ........... fulvicorne. Albay.

$b^{4}$. Antennæ deep green; inner crest nearly absent ............ Pirsutellum. Palawan.

\section{Genus Cyluosoma, nov.}

Tarsi as in Zephronia.

Vulva as in Zephronia, but the proximal plate divided into two distinct pieces, whereof the external partially overlaps the internal.

The movable digits of both pairs of copulatory forceps composed of a single segment.

Type C. angulatum (Butler).

Distribution. Eastern Australia, New Zealand.

$$
\text { Cyliosoma striolatum, sp. n. }
$$

Colour greenish black; terga covered with black spots. Terga densely punctulate throughout. 
Loc. Greymouth (New Zealand, South Island).

Allied to C. de Lacyi (White), from Waikato, but differs in having the punctuation finer and closer, in having the anal tergite compressed, and in being spotted with black. From liosoma (Hutton), from Dunedin, it may be recognized by having the infero-lateral portion of the tergites more strongly emarginate and the edge of the anal tergite laterally notched.

LV.-Descriptions of new Species of Planema in the Collection of the British Museum. By A. G. Butler, Ph.D. \&c.

WHILsT recently rearranging the Museum collection of Acrceinee of the Old World, and incorporating the fine series presented by Messrs. Godman and Salvin, I came upon the following undescribed species of Planema:-

\section{Planema Salvini, sp. n.}

Nearest to $P$. camerunica, the male with the discoidal area of primaries, the area below the cell, and the band crossing the centre of the wing golden orange instead of tawny; the transverse band itself more regular, especially along its outer margin; secondaries with the basal spots arranged as in $P$. formosa and followed by a diffused whitish band, more distinctly white on the under surface: the female chiefly differing from that sex of $P$. camerunica in the much less irregular inner edging of the white belt on the primaries (which is less distinctly continued below the first median branch) and its less prominent external angle, so that the deep-brown apical area is broader in this species: the secondaries much more nearly resemble those of the female of $P$. formosa, but the white belt across them is broader and more diffused. Expanse of wings, ot 75 millim., o 93 millim.

Fernando Po and Cameroons (from the Godman \& Salvin Collection).

The natural position of this species is undoubtedly between $P$. formosa and $P$. camerunica.

\section{Planema Godmani, sp. n.}

Allied to $P$. camerunica and $P$. alcinoe; the male has almost the same pattern on the primaries as the latter species, excepting that the inner blackish edging of the central band is usually almost wholly lost, so that these wings become 